\title{
Small-Scale Bioreactors for the Culture of Embryonic Stem Cells
}

\author{
Allison Van Winkle1,2, Ian D. Gates ${ }^{2}$ and Michael S. Kallos ${ }^{1,2}$ \\ ${ }^{1}$ Pharmaceutical Production Research Facility (PPRF), Schulich School of Engineering, \\ University of Calgary, Alberta, \\ 2Deparment of Chemical and Petroleum Engineering, Schulich School of Engineering, \\ University of Calgary, Alberta, \\ Canada
}

\section{Introduction}

Stem cells have great potential for use as a regenerative therapy for degenerative diseases, such as diabetes or Parkinson's. However, to create a large-scale and reproducible protocol, large homogeneous cell populations are required. For example, it is estimated that to treat one patient with stem cell-derived functional beta-cell equivalents for diabetes would require approximately 1 billion homogeneous beta-cell equivalents (Docherty et al. 2007). To reproducibly expand ESCs to this order remains a major research hurdle. Suspension bioreactors offer major advantages over traditional, static culture methods, including the ability to monitor and control important bioprocess parameters such as dissolved oxygen, $\mathrm{pH}$, and temperature. In addition, for clinical implementation of a stem cell therapy, automation associated with bioreactors will aid in compliance with regulatory protocols (Martin et al. 2009). Other advantages of suspension bioreactors over traditional (static) cell culture methods, include scalability, enhanced oxygen and nutrient transfer, homogeneity, and increased reproducibility. However, the use of larger-scale bioreactors (for example, greater than $100 \mathrm{~mL}$ working volume) incurs significant expenses as considerable amounts of media, cells, and other supplies are required. In addition, extensive time and handling is necessary to generate enough cells for inoculation. Small-scale bioreactors (less than $100 \mathrm{~mL}$ working volume) require fewer cells, are more economical, and require less labour than larger bioreactors. The use of small-scale bioreactors potentially permits high-throughput experimentation to test operating and growth conditions (media components, agitation rate, cell density) and the resulting interactions.

In a suspension bioreactor, cells are suspended in liquid medium which consists of a mixture of water, glucose, amino acids and dissolved oxygen, among other factors. As the suspension bioreactor is agitated, the environment within the bioreactor is more homogeneous than traditional culture environments, such as a T-flask, where gradients occur in the static media. The hydrodynamic environment created by agitation of the suspension bioreactor is known to influence cell survival. Excessive amounts of shear stress can lead to damage to cell membranes (Betts and Baganz 2006) whereas insufficient amounts of shear stress can cause excessive agglomeration ( $\mathrm{Li}$ et al. 2009). In addition, manipulating 
the amount of shear stress on cells has been found to influence the resulting diameter of mammalian neural stem cell aggregates (Sen et al. 2001) which in turn also influences the distances through which nutrients must diffuse.

\section{Stem cell culture in suspension bioreactors}

It is well established in literature that stem cells can be cultured in suspension bioreactors (Kallos and Behie 1999; Krawetz et al. 2009; Kwon et al. 2003; Niebruegge et al. 2009; Schroeder et al. 2005; Youn et al. 2005). As an example, murine embryonic stem cells have been successfully expanded in $100 \mathrm{~mL}$ suspension bioreactors within specific ranges of agitation rates and corresponding shear stresses. The mESCs were expanded over a period of 6 days. Three agitation rates were tested: 80, 100 and $120 \mathrm{rpm}$. mESC expansion was found to be greatest at $100 \mathrm{rpm}$ reaching a peak viable cell density of $10^{6}$ cells/mL. It was also observed that aggregate diameters in the $100 \mathrm{rpm}$ bioreactors were smaller than that of the $80 \mathrm{rpm}$ bioreactors whereas the $120 \mathrm{rpm}$ bioreactors resulted in excessive cell debris and no proliferation indicating substantial damage to the cells (Cormier et al. 2006).

Cormier et al. also examined the effect of cell culture in suspension bioreactors on pluripotency. Immunocytochemistry was examined for several mESC pluripotency markers: Oct-4, Nanog and SSEA-1, which are expressed in undifferentiated mESC cells, and downregulated once cells differentiate (Murphy and Polak 2002; Tavares et al. 2007). Samples were taken from static culture (prior to suspension culture) and on Day 4 of the suspension culture (within the exponential growth phase) and positive expression of all pluripotency markers were observed in both samples (Cormier et al. 2006).

mESCs have also been serially passaged in suspension bioreactors (zur Nieden et al. 2007). Aggregates were harvested on Day 4 (within the exponential growth phase), dissociated into single cells and re-inoculated at a cell density equal to $3.75 \times 10^{4}$ cells $/ \mathrm{mL}$. This procedure was repeated for seven subsequent passages; static cultures were maintained over the same time period. The suspension culture had a cumulative 2.5 billion-fold expansion over the 28 day period, whereas a control static culture had a 76.4 trillion fold expansion. However, as the static cultures were passaged every two days, there were twice as many static passages as suspension passages. Per passage, the suspension culture was found to have a 31-fold expansion whereas the static culture had a smaller 10-fold expansion. In addition, 37 static culture flasks would be required to obtain the total cell number as obtained from one suspension bioreactor (zur Nieden et al. 2007). While the amount of static culture flasks could be reduced by using larger static flasks, the homogeneity, reproducibility and reduced amount of labour motivate the use of suspension bioreactors for clinical applications.

Suspension bioreactors have been used to produce mesoderm and cardiac cells from hESCs however these cells were first cultured under static conditions on a layer of feeder cells and transferred into suspension culture after differentiation had begun (Niebruegge et al. 2009). The use of feeder cells decreases the amount of reproducibility and increases the risk of contamination and immune response; this protocol could not be used for clinical application.

The expansion of hESCs in a suspension bioreactor has been successful with the addition of Rho-associated kinase (ROCK) inhibitor which has been found to diminish dissociationinduced apoptosis for single cells (Li et al. 2009; Watanabe et al. 2007). Krawetz et al. exposed H9 hESCs to ROCK inhibitor for 24 hours and obtained a cell fold expansion of 25 over 6 days (Krawetz et al. 2009). Kehoe et al. exposed H1 hESCs to ROCK inhibitor for only 
30 minutes and obtained a cell fold expansion of 5.6 over 7 days (Kehoe et al. 2009). These researchers also used different media for the cell culture. In a $50 \mathrm{~mL}$ suspension bioreactor, Singh et al. (2010) cultured various hESC lines: hES2, hES3, ESI04 and found that culturing the cells in the presence of ROCK and a heat shock treatment resulted in the greatest amount of cell survival ( $60 \%$ cell survival with ROCK and heat shock treatment, compared to $2 \%$ in the control case). It was also found that all three cell lines formed comparably sized aggregates and resulted in approximate 2-fold cell expansion per passage. However, Singh et al. noted cell line differences in the maintenance of pluripotency within the suspension bioreactors; pluripotency markers remained high for the hES2 and hES3 lines, but Oct4, Tra160 and SSEA4 down regulated for the ESI049 hESC line (Singh et al. 2010).

Other research groups have reported successful expansion of hESCs in suspension culture where the suspension culture in this case is not a suspension bioreactor but rather a shake flask (Amit et al. 2010), low-attachment well plate (Olmer et al. 2010) or in some cases, not described (Rezaei Larijani et al. 2011; Steiner et al. 2010). The data obtained from these researchers provides valuable information about the hESCs ability to differentiate in suspension where hESCs were differentiated to neural cells in suspension (Steiner et al. 2010) and to neural, cardiomyocytes and hepatocytes in suspension (Rezaei Larijani et al. 2011). Additionally, the ability of hESCs to maintain stable karyotypes and maintain pluripotency in suspension was established (Amit et al. 2010; Olmer et al. 2010; Rezaei Larijani et al. 2011; Steiner et al. 2010). However, these cell culture strategies are not amenable to substantial scale-up for clinical purposes due to heterogeneity and lack of control over bioprocess parameters.

Another option for suspension culture of hESCs is using microcarriers which provide an adherent surface for the cells to grow on. hESCs have been successfully expanded in a longterm (6 months) suspension culture grown on microcarriers; the cells retained their pluripotency (as indicated by $>95 \%$ expression levels of SSEA4 and TRA-1-60 markers) reaching a cell density twice that of a static culture: 1.6 million cells $/ \mathrm{mL}$ as opposed to 0.8 million cells/mL (Oh et al. 2009). However, microcarrier cultures are disadvantageous for large scale production since the cells must be dissociated from the surface of the microcarrier and/or the microcarrier dissolved before clinical use.

While the results of hESCs cultured in suspension and in suspension bioreactors are promising, there is still substantial research to be performed regarding agitation rates, shear stress, and media components before hESCs can be successfully expanded in controlled bioprocesses to large clinically meaningful populations.

\section{Small-scale bioreactors}

Small-scale systems have traditionally been used for preliminary research such as screening a large number of experimental conditions. However, for process scale up, where the biological product obtained for a large-scale operation ( 5 to $100 \mathrm{~L}$ for mammalian cells) is equivalent to the small scale bioreactor product; many experiments are required to determine desired media components and operating conditions. However, the use of standard-scale bioreactors (100 mL working volume) incurs significant cost since considerable amounts of media, cells, and other supplies are required. In addition, extensive time and handling is necessary to generate enough cells for inoculation. A scalable, smallscale suspension bioreactor system would require fewer cells, and less labour than was 
previously possible with larger suspension bioreactors. High-throughput cell culture experiments at a more economical scale could then be performed for culture optimisation (Kostov et al. 2001) and allow for factorial experimental design.

While substantial research has been completed in the area of scaled-up production (Baghbaderani et al. 2008; Fernandes-Platzgummer et al. 2011; Garcia-Ochoa and Gomez 2009; Gilbertson et al. 2006; Park et al. 2010; Youn et al. 2005; Yu et al. 2009) to increase cell cultures to clinically meaningful numbers such as the estimated 1 billion cells per patient required for stem cell therapy (Docherty et al. 2007), there has been little development in scaling down mammalian cell bioreactor systems. Many scaled-down bioreactors in the literature have been developed to culture Escherichia coli (bacteria) or Saccharomyces cerevisiae (yeast). Some consist of shaken well plate systems (Duetz 2007; Elmahdi et al. 2003; Micheletti et al. 2006). In these systems, bacteria and yeast cultures are more mechanically srong and thus they can be agitated at substantially higher rates than mammalian cells (Betts and Baganz 2006). In addition, surface tension effects are more pronounced in shaken systems than in stirred configurations (Betts and Baganz 2006). Recently, many of the smallscale systems in literature have been changed from initial shaken models to a stirred design (Gill et al. 2008; Islam et al. 2007; Kusterer et al. 2008; Micheletti et al. 2006; Weuster-Botz et al. 2005).

There are many inconsistencies in the literature on the definition of a microbioreactor. This report will use the definitions of small-scale bioreactors as outlined in Table 1.

\begin{tabular}{|l|c|}
\hline Bioreactor & Working Volume \\
\hline Nanobioreactor & $<1 \mu \mathrm{L}$ \\
\hline Microbioreactor & $1 \leq \mathrm{v}<1000 \mu \mathrm{L}$ \\
\hline Minibioreactor & $1 \leq \mathrm{v}<100 \mathrm{~mL}$ \\
\hline Standard bioreactor & $100 \leq \mathrm{v}<500 \mathrm{~mL}$ \\
\hline Large bioreactor & $\geq 500 \mathrm{~mL}$ \\
\hline
\end{tabular}

Table 1. Working Volumes of Bioreactors

Industrial sized bioreactors can reach sizes much greater than $1 \mathrm{~L}$, but currently, large bioreactors of this size and beyond have not been needed for embryonic stem cell culture.

\subsection{Bacteria and yeast culture in small-scale bioreactors}

There are a number of different small-scale stirred bioreactor systems currently available in the literature all of which contain oxygen and $\mathrm{pH}$ sensors. The first was developed by the Lye group at University College, London. This bioreactor system was designed to be geometrically similar to large scale bioreactors, and driven by a miniature turbine impeller. They found that to ensure the impeller was submerged in liquid, and to achieve an agitation rate of up to $2000 \mathrm{rpm}$, the bioreactor was restricted to be $100 \mathrm{~mL}$ in size. The impeller was magnetically driven, and up to 16 reactors could be operated in parallel with continuous online monitoring and control of $\mathrm{pH}$, dissolved oxygen and temperature. The calculated maximum specific growth rate (of $E$. coli) and final biomass concentrations achieved were similar between the small-scale bioreactor and a conventional large-scale $2 \mathrm{~L}$ bioreactor. The group concluded that results obtained from small-scale parallel experiments in the miniature bioreactors can thus be converted to large-scale bioreactors (Gill et al. 2008). While 
this conclusion is valid, the work was performed on a bioreactor which is considered standard-sized for lab-scale mammalian cell experimentation, and the bioreactor system presented by the Lye group is not suitable for high-throughput analysis.

A second small-scale bioreactor system was developed by the Weuster-Botz group from Technische Universitat, Germany. This minibioreactor system uses a 48-reactor block of magnetically stirred bioreactors each one of the order of $10 \mathrm{~mL}$ scale. Dissolved oxygen and $\mathrm{pH}$ are measured by chemical sensors. Sampling and acid or base additions were carried out by a robotic liquid handling system with up to $20 \mu \mathrm{L}$ sampled every 1 to 4 hours. This sample was read by a microtitre plate fluorescence reader, in which the optical density was correlated to cell density. The growth characteristics of E. coli and S. cerevisiae were similar at the $10 \mathrm{~mL}$ and $20 \mathrm{~L}$ scale (Kusterer et al. 2008). The above system has recently been modified with a new impeller for the culture of mycelium forming microorganisms. These cultivations are more prominently affected by shear forces than bacteria or yeast cultures as shear stress effects the morphology and productivity of these cells (Hortsch et al. 2010). Additionally, the culture broth is a non-Newtonian, shear-thinning fluid (Pollard et al. 2002) with lower viscosity at higher shear rates which influences mixing, heat and mass transfer processes within the bioreactor. The new impeller developed by this group aimed to ensure sufficient gas-liquid mass transfer for the cultured Streptomyces tendae. The impeller is a vertical, one-sided paddle which distributes power throughout the reactor, resulting in consistent viscosity throughout the reactor.

The $10 \mathrm{~mL}$ bioreactors were agitated at $1200 \mathrm{rpm}$. Reference cultivations were cultured in a 3L stirred tank bioreactor (impeller speed was equal to $800 \mathrm{rpm}$ ) where the power input was held constant between the two bioreactor sizes. The production of nikkomycin $\mathrm{Z}$ was compared between the two scales and it was found that approximately $300 \mathrm{mg} \mathrm{L}^{-1}$ were produced at each size scale (Hortsch et al. 2010). However, while these agitation rates are lower than that used for bacterial or yeast cultures, they are still much higher than that which mammalian cells could sustain.

A third small-scale bioreactor system was developed by the Rao group of the University of Maryland. A $2 \mathrm{~mL}$ minibioreactor was developed, and the volumetric mass transfer coefficient $\left(\mathrm{k}_{\mathrm{L}} \mathrm{a}\right)$ was kept constant from the small-scale bioreactor up to $1 \mathrm{~L}$, based on the rational that higher $\mathrm{k}_{\mathrm{L}} \mathrm{a}$ may yield increased cell growth due to oxygen availability, and $\mathrm{k}_{\mathrm{L}} \mathrm{a}$ should thus be kept constant for scalability between the two systems. It was observed that oxygen depletion patterns between the two systems were similar during exponential growth. The total cost of the bioreactor system was less than US\$400 (in 2001); the Rao group proposes that it seems possible to develop a bioprocess system where many bioprocesses can run in parallel (96 or more) for lower cost than a bench scale bioreactor. However, the system was magnetically stirred by a stir-bar located on the bottom of the vessel (Kostov et al. 2001). This arrangement, with the stir bar free-floating in the system, has been found to be detrimental to mESC expansion; it is hypothesized that the stir bar, sitting on the bottom of the vessel, effectively crushes the cells as they are pulled underneath (Millar 2009).

The Rao group has also developed an additional minibioreactor with a working volume of 10 to $35 \mathrm{~mL}$ agitated with an impeller, for the cultivation of bacteria and yeast (Harms et al. 2006). The design of the bioreactor agitation system has not been published other than to specify that the small-scale bioreactors are stirred and each well is controlled by an 
individual stepper motor. The use of an individual motor for each well would provide opportunity for agitation rate testing in multiples on a small scale, but not yet to the small micro-scale desired in this study. In addition, increasing the number of motors used vastly increases the cost and operational complexity of the system.

A fourth small-scale reactor, developed by the Jensen group at the Massachusetts Institute of Technology was also designed for bacteria and yeast culture, and is the smallest stirred small-scale reactor to be found in the literature at 0.1 to $1.0 \mathrm{~mL}$ in working volume. The most recent form of this microbioreactor has the impeller extend upward from the base of the reactor; $100 \mu \mathrm{L}$ volumes were found to replicate the growth kinetics and gene expression profiles of $E$. coli as in a $0.5 \mathrm{~L}$ bioreactor (Zhang et al. 2007). While these results are promising, an array for parallel experimentation has not yet been developed (a single reactor only) and the location of the impeller at the base of the reactor would make operation (cleaning and sterilizing) difficult.

\subsection{Mammalian cell culture in small-scale bioreactors}

To date, there has not been any scaled-down stirred, suspension bioreactors published for mammalian cell culture. However, there have been developments relating to small-scale mammalian cell culture devices to investigate the cell microenvironment (Cimetta et al. 2009; Figallo et al. 2007; Wu et al. 2006). These devices are not amenable to scaled-up production, or high-throughput screening for bioreactor cultivations, since bioreactor hydrodynamics are not designed to be similar to a standard bioreactor but they are designed rather to study the cell microenvironment. In addition, these systems are perfusion based allowing for constant exchange of nutrients for waste; while this is beneficial for cell culture, it is in contrast to the batch cultivations of a stirred-tank bioreactor which this chapter has focused on.

Small-scale hollow-fiber devices for use as a bioartificial liver are also being developed (Gramer and Britton 2002; Rodriguez et al. 2008). However, these reactors are designed for cell product secretion, and not for cell expansion, and again are not amenable to scaled-up expansion of stem cells.

There have been developments for mammalian cell culture in small-scale shaken bioreactors. Chinese Hamster Ovary $(\mathrm{CHO})$ cells were cultivated in a small-scale shaken bioreactor, equipped with a ventilation cap. The small-scale bioreactor has a footprint of a 24 well-plate, and each vial has a working volume of $6 \mathrm{~mL}$ (Isett et al. 2007). The cell growth and metabolite profiles in th $6 \mathrm{~mL}$ bioreactor were found to be similar when compared to a large-scale $2 \mathrm{~L}$ bioreactor culture where $85 \%$ of the viable cell density of $\mathrm{CHO}$ cells cultured in the small-scale bioreactor was within $20 \%$ of the viable cell density of $\mathrm{CHO}$ cells cultured in the 2L bioreactor (Chen et al. 2008). While this is a promising result, the size scale remains a barrier to high throughput screening, and no engineering calculations were done to show a comparison of the bioreactor hydrodynamics between the two size scales.

Girard et al. (2001) also cultured CHO cells in a small-scale shaken bioreactor; the cells were cultured in the wells of a twelve-well microtiter plate and shaken on a rotational shaker plate. As the well plates are stackable, several hundred small-scale bioreactor experiments were able to be reproducibly completed. Cell density was measured with the use of fluorescence measurements, which allows for non-invasive sampling. In this study, the formation of cellular aggregates was compared between the shaken well plate small-scale bioreactor ( $2 \mathrm{~mL}$ working volume) and a $3 \mathrm{~L}$ stirred bioreactor and the resulting cell aggregate size was found to be comparable. The two systems were also compared with respect to production of protein where the small-scale bioreactor resulted in double the 
production of protein from the standard bioreactor. However, the results also indicated that evaporation was a problem within the small-scale bioreactor which led to inconsistencies in the results (Girard et al. 2001).

$\mathrm{CHO}$ cells have also been cultivated in a $700 \mu \mathrm{L}$ microbioreactor; cultures were inoculated in small chambers of a plastic card with diffusible walls for oxygen and carbon dioxide mass transfer. The cards were then rotated. The cell culture behaved similarly to a $3 \mathrm{~L}$ large-scale bioreactor, where the correlation factor, $\mathrm{R}^{2}$, between the two scales for the resulting viable cell density was equal to 0.84 . In addition, the small-scale bioreactor was used to analyse the process in a high throughput manner; finding that supplementing the media substantially ( $\mathrm{p}$ $<0.05$ ) affected the cells resulting in a higher cell mass. However, due to the small volumes used, Legmann et al. noticed significant differences in the cell counts from the microbioreactors (Legmann et al. 2009).

By using agitation induced by thermal convection, a $250 \mu \mathrm{L}$ microbioreactor has been developed for expansion of human hematopoietic stem cells. The temperature gradient within the microbioreactor was small ranging from 36.0 to $36.015^{\circ} \mathrm{C}$, where the heat source was provided at the base of the reactor. This resulted in temperatures suitable for mammalian cell culture. Experimental tests comparing the microbioreactor culture to a static control resulted in no statistically significant effect on the cell proliferation rate (Luni et al. 2010). Thus, while this microbioreactor yields successful cell expansion, it does not result in the large degree of enhanced cell expansion seen in suspension bioreactors as compared to static controls such as the 31-fold expansion observed in a standard $100 \mathrm{~mL}$ bioreactor as compared to 10-fold expansion in a static control (Cormier et al. 2006). Thermal convection mixing may provide a cell culture environment not significantly different from the static control. In addition, this system would be difficult to scale up because increasing large temperature gradients would be required which could be higher than viability threshold temperatures for mammalian cells.

\subsection{Small-scale bioreactors operating in parallel}

While the creation of a small-scale bioreactor for cell culture is indeed beneficial for research, small-scale bioreactors must be capable of operating in parallel with many other small-scale bioreactors for high-throughput experimentation and factorial analysis. The degree of parallel application found in small-scale bioreactors throughout the literature is presented in Table 2. Most small-scale bioreactors found in the literature are not yet amenable to high-throughput analysis while maintaining consistent hydrodynamic environments as a stirred standard scale bioreactor.

\begin{tabular}{|c|c|c|}
\hline Research & Bioreactor Scale & $\begin{array}{c}\text { Number of Bioreactors } \\
\text { Operating in Parallel }\end{array}$ \\
\hline Gill et al. 2008 & Standard $(100 \mathrm{~mL})$ & $4-16$ \\
\hline Kusterer et al. 2008 & Minibioreactor $(12 \mathrm{~mL})$ & 48 \\
\hline Isett et al. 2007 & Minibioreactor $(6 \mathrm{~mL})$ & 24 \\
\hline Girard et al. 2001 & Minibioreactor $(2 \mathrm{~mL})$ & $12-144$ \\
\hline Legmann et al. 2009 & Microbioreactor $(700 \mu \mathrm{L})$ & 180 \\
\hline
\end{tabular}

Table 2. Parallel Application of Small-Scale Bioreactors. The number of bioreactors at each size scale is presented. 
Applying parallel operation to bioreactors from a single prototype results in a number of complications. For example, Gill et al. found that the magnetically agitated bioreactor impeller design must be altered when creating a parallel application to avoid interacting magnetic fields. Due to the impeller design changes, the researchers found that the bioreactors must be agitated at speeds greater than $1000 \mathrm{rpm}$ to maintain a homogeneous gas bubble distribution within the culture media (Gill et al. 2008). Maintaining sterility has also been noted as an obstacle to parallelization, in particular during culture sampling. Kusterer et al. found that washing the components encountering sampling needles with a mixture of $70 \%$ ethanol (v/v) and $20 \%$ acetone (v/v) to be sufficient (Kusterer et al. 2008). However, cross-contamination between samples must also be avoided where each vessel must be treated as an individual sample with individual sampling ports. Girard et al. accomplished this through measuring cell growth via green fluorescent protein expressing cells and a fluorescence plate reader (Girard et al. 2001). Success with this method is thus dependent on a green fluorescent protein expressing cell line. Isett et al. also used fluorescence to monitor dissolved oxygen level (Isett et al. 2007). While Legmann et al. were able to successfully culture the mammalian cells in parallel microbioreactors, the hydrodynamics of the microbioreactor developed would not relate to a standard bioreactor.

\subsection{Hydrodynamic environment of small-scale bioreactors}

The hydrodynamic environment in a bioreactor is known to be a function of the bioreactor and impeller geometries, agitation rate, medium viscosity and volume (Flickinger and Drew 1999; King and Miller 2007; Marks 2003; Sen et al. 2002). When scaling reactors up, from lab scale to an industrial scale, it is common to hold several parameters constant to maintain a consistent hydrodynamic environment. This method may also be used for scaling down the size of reactors. It is common to maintain dimensional similarity (Flickinger and Drew 1999) such as a liquid height to reactor diameter ratio. However, these calculations do not consider the effect of shear stress on mammalian cells. These cells are very sensitive to shear stress due to the absence of a cell wall; high agitation rates can adversely affect mammalian cell growth (Betts and Baganz 2006).

While research results from the literature suggest small-scale bioreactors as potential technology for use in high throughput screening (Barrett et al. 2010; Betts and Baganz 2006; Kumar et al. 2004) and cells cultured in small-scale reactors have reached cell densities similar to that of large-scale bioreactors (Gill et al. 2008; Kusterer et al. 2008; Zhang et al. 2007), there remains a knowledge gap of the fluid behaviour between the two scales. For example, correlations and dimensionless numbers used to characterize systems at the largescale may not be applicable at the small scale. The Reynolds number, often used to characterize fluid systems, has been found to not be applicable at the micro-scale (Betts et al. 2006; Micheletti and Lye 2006; Vallejos et al. 2006). In addition, shear stress has been found to be a critical factor to maintaining cell cultures in suspension in bioreactors (Sen et al. 2001). The maximum shear stress on an aggregate in suspension is calculated as a function of fluid density and power dissipated per unit mass (Cherry and Kwon 1990; Sen et al. 2002) which is in turn a function of the Power Number. A correlation between the Power Number, Reynold's Number, and the reactor geometry has been developed (Nagata 1975). The Reynold's Number and Power Number are dimensionless numbers which act as a 
representation of physical forces. The Reynold's Number (Re) is a ratio of inertial to viscous forces, and is calculated as:

$$
R e=\frac{\rho U D}{\mu}
$$

Where $\rho$ is the fluid density $\left(\mathrm{kg} / \mathrm{m}^{3}\right), \mathrm{U}$ is the fluid velocity $(\mathrm{m} / \mathrm{s}), \mathrm{D}$ is a characteristic length of the system $(\mathrm{m})$ and $\mu$ is the fluid viscosity (Pa*s). The Power Number relates the resistance force to the intertial force, and is calculated for a reactor system as follows, using the shear stress within the system.

The maximum shear stress for a suspended sphere (aggregate) in turbulence can be found from the following equation (Cherry and Kwon 1990; Sen et al. 2002):

$$
\tau_{\max }=5.33 \rho \sqrt{\varepsilon \vartheta}
$$

where $\tau_{\max }$ is the maximum shear stress on an aggregate $(\mathrm{Pa})$, and $\varepsilon$ is the power dissipated per unit mass $\left(\mathrm{m}^{2} / \mathrm{s}^{3}\right)$, which is calculated as:

$$
\varepsilon=\frac{P}{V_{L} \rho}
$$

where $P$ is the power consumed $\left(\mathrm{kg} \mathrm{m}^{2} / \mathrm{s}^{3}\right)$, and $V_{L}$ is the liquid volume $\left(\mathrm{m}^{3}\right)$. The power consumed can be calculated as:

$$
P=P_{N} N^{3} D^{5} \rho
$$

where $\mathrm{P}_{\mathrm{N}}$ is the Power Number (dimensionless). The power number has been correlated to be a function of the Reynolds number and the physical properties of the bioreactor. The empirical correlation is as follows for an unbaffled tank with paddle impellers (Nagata 1975):

$$
P_{N}=\frac{K_{1}}{R e}+K_{2}\left[\frac{10^{3}+1.2 R e^{0.66}}{10^{3}+3.2 R e^{0.66}}\right]^{K_{4}}
$$

where

$$
\begin{gathered}
K_{1}=14+\frac{W}{D_{t}}\left[670\left(\frac{D_{i}}{D_{t}}-0.6\right)^{2}+185\right] \\
K_{2}=10^{K_{3}} \\
K_{3}=1.3-4\left[\frac{W}{D_{t}}-0.5\right]^{2}-1.14 \frac{D_{i}}{D_{t}} \\
K_{4}=1.1+4 \frac{W}{D_{t}}-2.5\left[\frac{D_{i}}{D_{t}}-0.5\right]^{2}-7\left[\frac{W}{D_{t}}\right]^{4}
\end{gathered}
$$

where $W$ is the impeller width $(\mathrm{m}), D_{t}$ is the tank diameter $(\mathrm{m})$ and $D_{i}$ is the impeller diameter (m).

When calculations are performed with these correlations to try to determine the shear forces on cells within the small-scale bioreactors, the resulting agitation rate needed to maintain 
the same shear as present in the larger bioreactor is much too high to sustain mammlian cell growth. Specifically, these correlations strongly depend on the Reynolds number. The use of a specific Reynolds number as a guide for the transition from laminar to turbulent flow has been found inapplicable to small-scale systems such as a microbioreactor (Betts et al. 2006; Micheletti and Lye 2006; Vallejos et al. 2006). At larger scales, the Reynold's number clearly represents the transition from laminar to turbulent flow. In addition, as these correlations were developed for a large-scale reactor, they may also not be applicable on a very smallscale.

\subsection{Oxygen environment in small-scale bioreactors}

Typically, stem cell bioreactors use surface aeration to supply oxygen to the suspended cells. The surface area to volume ratio in smaller bioreactors is much larger than the standard 100 $\mathrm{mL}$ bioreactors, as shown in Table 3. For embryonic stem cells in suspension culture, the mass transfer of oxygen has been found not to be a limiting factor (Cormier et al. 2006).

\begin{tabular}{|l|c|c|}
\hline Dimension & $\begin{array}{c}\text { Standard Bioreactor } \\
\mathbf{( 1 0 0 ~} \mathbf{~ m L})\end{array}$ & $\begin{array}{c}\text { Microbioreactor } \\
\mathbf{( 2 5 0} \boldsymbol{\mu L})\end{array}$ \\
\hline Volume $\left(\mathrm{m}^{3}\right)$ & $1.00 \mathrm{E}-04$ & $2.50 \mathrm{E}-07$ \\
\hline Surface Area $\left(\mathrm{m}^{2}\right)$ & $2.68 \mathrm{E}-03$ & $3.12 \mathrm{E}-05$ \\
\hline Surface Area/Volume $\left(\mathrm{m}^{-1}\right)$ & $2.68 \mathrm{E}+01$ & $1.25 \mathrm{E}+02$ \\
\hline
\end{tabular}

Table 3. Surface area to volume ratio of the standard $100 \mathrm{~mL}$ bioreactor and an example microbioreactor.

The following calculations were performed to characterize the mass transfer of oxygen to mESCs in a $250 \mu \mathrm{L}$ microbioreactor. The oxygen consumption rate of mESCs in suspension has been previously measured (zur Nieden et al. 2007). Assuming a peak cell density of $10^{6}$ cells/mL and a $250 \mu \mathrm{L}$ working volume, the peak consumption rate of oxygen of the cells in a microbioreactor vial can be determined. A total vessel volume of $1 \mathrm{~mL}$ is assumed. By using the ideal gas law, the amount of oxygen in the headspace $(0.75 \mathrm{~mL})$ is equal to $2.95 \times 10^{-}$ ${ }^{5} \mathrm{~mol}(0.94 \mathrm{mg})$. Assuming no oxygen transfer from the surrounding environment, where the oxygen in the headspace is the only oxygen available to the cells, and knowing the total oxygen consumption of the microbioreactor (Table 4), the amount of time required for the oxygen in the headspace to completely deplete was found to be 34 days, given a constant cell density of $10^{6}$ cells $/ \mathrm{mL}$. While it is unlikely that the cells would remain at a constant cell density, this density is the maximum found in standard $100 \mathrm{~mL}$ bioreactors, and thus represents a worst case scenario. It is more likely that the cell density would initially begin at a much smaller value, and then as the cells expanded the cell density would increase to $10^{6}$ cells $/ \mathrm{mL}$. In addition, as the microbioreactor vial would be opened much more frequently than this for sampling or media changes, there is thus an abundant supply of oxygen available to the cells. 


\begin{tabular}{|c|c|}
\hline Description & Value \\
\hline Specific Oxygen Consumption Rate & $4 \times 10^{-17 \frac{\mathrm{mol} \mathrm{O}_{2}}{\mathrm{cell} \cdot \mathrm{s}}}$ \\
\hline Cell Density & $10^{6} \mathrm{cells} / \mathrm{mL}$ \\
\hline Media Volume & $0.25 \mathrm{~mL}$ \\
\hline Total Cells & $2.5 \times 10^{5} \mathrm{cells}$ \\
\hline Total Oxygen Consumption & $1 \times 10^{-11} \frac{\mathrm{mol}}{\mathrm{s}}$ \\
\hline
\end{tabular}

Table 4. Oxygen consumption by murine embryonic stem cells in a microbioreactor. The cell density is assumed to be the peak cell density found by Cormier et al. 2006 and the oxygen consumption rate is as determined by zur Nieden et al. 2007.

The above calculations assume no mass transfer resistance from the bulk gas, through the liquid media to the cells, and that the consumption of oxygen by the cells is the limiting step. To instead consider the mass transfer of oxygen from the headspace to the liquid media as the limiting step, the following equation may be used to calculate the oxygen transfer rate:

$$
\text { OTR }=k_{L} a\left(C_{\text {sat }}-C_{B}\right)
$$

Where $k_{L} a$ is the volumetric mass transfer coefficient $\left(\mathrm{h}^{-1}\right), C_{s a t}$ is the saturation concentration of oxygen in the liquid $(\mathrm{mol} / \mathrm{L})$ and $\mathrm{C}_{\mathrm{B}}$ is the steady state bulk concentration of oxygen in the liquid (mol/L). The value for the mass transfer coefficient was the same as used by Millar (2009) $\left(\mathrm{k}_{\mathrm{L}} \mathrm{a}=2 \mathrm{~h}^{-1}\right)$. The solubility of oxygen (from standard air) in water used was $\mathrm{C}_{\text {sat }}=2.5 \times 10^{-4} \mathrm{~mol} / \mathrm{L}$ or $8 \mathrm{mg} / \mathrm{L}$ (Lenntech 2009). The steady state bulk concentration was calculated using a mass balance, and found to be equal to $8.85 \times 10^{-6}$ $\mathrm{mol} / \mathrm{L}(0.28 \mathrm{mg} / \mathrm{L})$. With these values, an oxygen transfer rate of $4.82 \times 10^{-4} \mathrm{~mol} / \mathrm{Lh}$ was found. Using this oxygen transfer rate, in combination with the amount of oxygen in the headspace calculated earlier in this section $\left(2.95 \times 10^{-5} \mathrm{~mol}\right)$, it was calculated that with the mass transfer of oxygen as the limiting step, there is enough oxygen in the microbioreactor to supply the media with oxygen for 244 hours (10 days). This value, while smaller than that found when the cell consumption was considered the limiting step, is still long enough for cell culture experiments, where cell counts are normally taken once per day, where the oxygen supply to the headspace would then be replenished.

Thus for the majority of cell culture experiments, a closed microbioreactor system provides a sufficient supply of oxygen. For long term experiments, or if cell samples were not taken more frequently than once per week, an oxygen supply may need to be considered as an alternative design.

\section{Conclusions}

Embryonic stem cells are considered to be a source of cells with tremendous potential for regenerative medicine, as they are capable of self-renewal and can differentiate into any cell type. The bioprocessing of these cells (i.e. creating reliable protocols for cell expansion and differentiation) is a critical component of developing therapies ready for clinical implementation. Suspension bioreactors are understood to be a scalable, reproducible and 
reliable method for cell expansion in the biotechnology industry. It is well established that a small-scale bioreactor system would be beneficial for stem cell research. Microbioreactor systems available in the literature, primarily developed for bacterial and yeast cultures, were reviewed and the applications for mammalian, or stem cell cultures were considered. However, the fluid environment at this scale remains largely uncharacterised, and bioreactor scale-down for cell culture has been shown to not be a linear process. Hydrodynamic studies and modeling of the shear and mass transfer environment at this small-scale would benefit this field in the development of a small-scale bioreactor applicable for embryonic stem cell expansion and differentiation.

\section{References}

Amit M, Chebath J, Margulets V, Laevsky I, Miropolsky Y, Shariki K, Peri M, Blais I, Slutsky G, Revel M and others. 2010. Suspension culture of undifferentiated human embryonic and induced pluripotent stem cells. Stem Cell Rev 6(2):248-59.

Baghbaderani B, A. , Mukhida K, Sen A, Hong M, Mendez I, Behie L, A. 2008. Expansion of Human Neural Precursor Cells in Large-Scale Bioreactors for the Treatment of Neurodegenerative Disorders. Biotechnology Progress 24(4):859-870.

Barrett TA, Wu A, Zhang H, Levy MS, Lye GJ. 2010. Microwell engineering characterization for mammalian cell culture process development. Biotechnol Bioeng 105(2):260-75.

Betts JI, Baganz F. 2006. Miniature bioreactors: current practices and future opportunities. Microb Cell Fact 5:21.

Betts JI, Doig SD, Baganz F. 2006. Characterization and application of a miniature $10 \mathrm{~mL}$ stirred-tank bioreactor, showing scale-down equivalence with a conventional $7 \mathrm{~L}$ reactor. Biotechnol Prog 22(3):681-8.

Chen A, Chitta A, Chang D, Amanullah A. 2008. Twenty-four well plate miniature bioreactor system as a scale-down model for cell culture process development. Biotechnology and bioengineering 102(1):148-160.

Cherry R, S., Kwon K-Y. 1990. Transient shear stresses on a suspension cell in turbulence. Biotechnology and bioengineering 36(6):563-571.

Cimetta E, Figallo E, Cannizzaro C, Elvassore N, Vunjak-Novakovic G. 2009. Microbioreactor arrays for controlling cellular environments: Design principles for human embryonic stem cell applications. Methods 47(2):81-89.

Cormier JT, zur Nieden NI, Rancourt DE, Kallos MS. 2006. Expansion of undifferentiated murine embryonic stem cells as aggregates in suspension culture bioreactors. Tissue Eng 12(11):3233-45.

Docherty K, Bernardo AS, Vallier L. 2007. Embryonic stem cell therapy for diabetes mellitus. Semin Cell Dev Biol. England. p 827-38.

Duetz WA. 2007. Microtiter plates as mini-bioreactors: miniaturization of fermentation methods. Trends Microbiol 15(10):469-75.

Elmahdi I, Baganz F, Dixon K, Harrop T, Sugden D, Lye GJ. 2003. pH control in microwell fermentations of S. erythraea CA340: Influence on biomass growth kinetics and erythromycin biosynthesis. Biochemical Engineering Journal 16(3):299-310.

Fernandes-Platzgummer A, Diogo MM, da Silva CL, Cabral JM. 2011. Large-scale expansion of mouse embryonic stem cells on microcarriers. Methods Mol Biol 690:121-34. 
Figallo E, Cannizzaro C, Gerecht S, Burdick JA, Langer R, Elvassore N, Vunjak-Novakovic G. 2007. Micro-bioreactor array for controlling cellular microenvironments. Lab Chip 7(6):710-9.

Garcia-Ochoa F, Gomez E. 2009. Bioreactor scale-up and oxygen transfer rate in microbial processes: An overview. Biotechnology Advances 27(2):153-176.

Gilbertson J, A. , Sen A, Behie L, A., Kallos M, S. 2006. Scaled-up production of mammalian neural precursor cell aggregates in computer-controlled suspension bioreactors. Biotechnology and bioengineering 94(4):783-792.

Gill NK, Appleton M, Baganz F, Lye GJ. 2008. Design and characterisation of a miniature stirred bioreactor system for parallel microbial fermentations. Biochemical engineering journal 39(1):164-176.

Girard P, Jordan M, Tsao M, Wurm FM. 2001. Small-scale bioreactor system for process development and optimization. Biochem Eng J 7(2):117-119.

Gramer M, J., Britton T, L. 2002. Antibody production by a hybridoma cell line at high cell density is limited by two independent mechanisms. Biotechnology and bioengineering 79(3):277-283.

Harms P, Kostov Y, French JA, Soliman M, Anjanappa M, Ram A, Rao G. 2006. Design and performance of a 24-station high throughput microbioreactor. Biotechnol Bioeng 93(1):6-13.

Hortsch R, Stratmann A, Weuster-Botz D. 2010. New milliliter-scale stirred tank bioreactors for the cultivation of mycelium forming microorganisms. Biotechnol Bioeng 106(3):443-51.

Isett K, George H, Herber W, Amanullah A. 2007. Twenty-four-well plate miniature bioreactor high-throughput system: assessment for microbial cultivations. Biotechnol Bioeng 98(5):1017-28.

Islam RS, Tisi D, Levy MS, Lye GJ. 2007. Framework for the rapid optimization of soluble protein expression in Escherichia coli combining microscale experiments and statistical experimental design. Biotechnology Progress 23(4):785-793.

Kallos MS, Behie LA. 1999. Inoculation and growth conditions for high-cell-density expansion of mammalian neural stem cells in suspension bioreactors. Journal of Engineering and Applied Science 63(4):473-483.

Kehoe DE, Jing D, Lock LT, Tzanakakis ES. 2009. Scalable Stirred-Suspension Bioreactor Culture of Human Pluripotent Stem Cells. Tissue Engineering Part A 0(0).

Kostov Y, Harms P, Randers-Eichhorn L, Rao G. 2001. Low-cost microbioreactor for highthroughput bioprocessing. Biotechnol Bioeng 72(3):346-52.

Krawetz R, Taiani JT, Liu S, Meng G, Li X, Kallos MS, Rancourt DE. 2009. Large-Scale Expansion of Pluripotent Human Embryonic Stem Cells in Stirred-Suspension Bioreactors. Tissue Engineering Part C: Methods 16(4):573-582.

Kumar S, Wittmann C, Heinzle E. 2004. Minibioreactors. Biotechnol Lett 26(1):1-10.

Kusterer A, Krause C, Kaufmann K, Arnold M, Weuster-Botz D. 2008. Fully automated single-use stirred-tank bioreactors for parallel microbial cultivations. Bioprocess Biosyst Eng 31(3):207-15.

Kwon J, Kim BS, Kim MJ, Park HW. 2003. Suspension culture of hematopoietic stem cells in stirred bioreactors. Biotechnol Lett 25(2):179-82. 
Legmann R, Schreyer HB, Combs R, G., McCormick E, L., Russo AP, Rodgers S, T. 2009. A predictive high-throughput scale-down model of monoclonal antibody production in CHO cells. Biotechnology and bioengineering 104(6):1107-1120.

Li X, Krawetz R, Liu S, Meng G, Rancourt DE. 2009. ROCK inhibitor improves survival of cryopreserved serum/feeder-free single human embryonic stem cells. Hum. Reprod. 24(3):580-589.

Luni C, Feldman HC, Pozzobon M, De Coppi P, Meinhart CD, Elvassore N. 2010. Microliterbioreactor array with buoyancy-driven stirring for human hematopoietic stem cell culture. Biomicrofluidics 4(3).

Martin I, Smith T, Wendt D. 2009. Bioreactor-based roadmap for the translation of tissue engineering strategies into clinical products. Trends Biotechnol. England. p 495-502.

Micheletti M, Barrett T, Doig SD, Baganz F, Levy MS, Woodley JM, Lye GJ. 2006. Fluid mixing in shaken bioreactors: Implications for scale-up predictions from microlitrescale microbial and mammalian cell cultures. Chemical Engineering Science 61(9):2939-2949.

Micheletti M, Lye GJ. 2006. Microscale bioprocess optimisation. Curr Opin Biotechnol. England. p 611-8.

Millar VF. 2009. Development of Microbioreactors for Embryonic Stem Cell Bioprocess Design [MSc. Thesis]. Calgary, Alberta: University of Calgary.

Murphy CL, Polak JM. 2002. Differentiating Embryonic Stem Cells: GAPDH, But Neither HPRT Nor $\hat{I}^{2}$-Tubulin Is Suitable as an Internal Standard for Measuring RNA Levels. Tissue engineering 8(4):551-559.

Nagata S. 1975. Mixing: Principles and Applications: Wiley: New York

Niebruegge S, Bauwens C, Peerani R, Thavandiran N, Masse S, Sevaptisidis E, Nanthakumar K, Woodhouse K, Husain M, Kumacheva E and others. 2009. Generation of human embryonic stem cell-derived mesoderm and cardiac cells using size-specified aggregates in an oxygen-controlled bioreactor. Biotechnology and bioengineering 102(2):493-507.

Oh SKW, Chen AK, Mok Y, Chen X, Lim UM, Chin A, Choo ABH, Reuveny S. 2009. Longterm microcarrier suspension cultures of human embryonic stem cells. Stem Cell Research 2(3):219-230.

Olmer R, Haase A, Merkert S, Cui W, Palecek J, Ran C, Kirschning A, Scheper T, Glage S, Miller K and others. 2010. Long term expansion of undifferentiated human iPS and ES cells in suspension culture using a defined medium. Stem Cell Res. England: 2010 Elsevier B.V. p 51-64.

Park Y, Subramanian K, Verfaillie CM, Hu WS. 2010. Expansion and hepatic differentiation of rat multipotent adult progenitor cells in microcarrier suspension culture. Journal of Biotechnology 150(1):131-139.

Pollard DJ, Hunt G, Kirschner TK, Salmon PM. 2002. Rheological characterization of a fungal fermentation for the production of pneumocandins. Bioprocess and Biosystems Engineering 24(6):373-383.

Rezaei Larijani M, Seifinejad A, Pournasr B, Hajihoseini V, Hasani N, Totonchi M, Yousefi M, Shamsi F, Salekdeh GH, Baharvand H. 2011. Long-term Maintenance of 
Undifferentiated Human Embryonic and Induced Pluripotent Stem Cells in Suspension. Stem Cells Dev.

Rodriguez J, V. , Pizarro MD, Scandizzi A, L., Guibert E, E., Almada L, L., Mamprin M, E. . 2008. Construction and Performance of a Minibioreactor Suitable as Experimental Bioartificial Liver. Artificial Organs 32(4):323-328.

Schroeder M, Niebruegge S, Werner A, Willbold E, Burg M, Ruediger M, Field LJ, Lehmann J, Zweigerdt R. 2005. Differentiation and lineage selection of mouse embryonic stem cells in a stirred bench scale bioreactor with automated process control. Biotechnology and Bioengineering 92(7):920-933.

Sen A, Kallos MS, Behie LA. 2001. Effects of Hydrodynamics on Cultures of Mammalian Neural Stem Cell Aggregates in Suspension Bioreactors. Industrial \& Engineering Chemistry Research 40(23):5350-5357.

Sen A, Kallos MS, Behie LA. 2002. Expansion of mammalian neural stem cells in bioreactors: effect of power input and medium viscosity. Developmental Brain Research 134(12):103-113.

Singh H, Mok P, Balakrishnan T, Rahmat SN, Zweigerdt R. 2010. Up-scaling single cellinoculated suspension culture of human embryonic stem cells. Stem Cell Res. England: 2010 Elsevier B.V. p 165-79.

Steiner D, Khaner H, Cohen M, Even-Ram S, Gil Y, Itsykson P, Turetsky T, Idelson M, Aizenman E, Ram R and others. 2010. Derivation, propagation and controlled differentiation of human embryonic stem cells in suspension. Nat Biotechnol. United States. p 361-4.

Tavares R, Xu K, Zhang C, de Freitas V. 2007. A specific and quick gene expression study in mouse ES cells. Journal of Assisted Reproduction and Genetics 24(8):366-372.

Vallejos JR, Kostov Y, Ram A, French JA, Marten MR, Rao G. 2006. Optical Analysis of Liquid Mixing in a Minibioreactor. Biotechnol Bioeng 93:906-911.

Watanabe K, Ueno M, Kamiya D, Nishiyama A, Matsumura M, Wataya T, Takahashi JB, Nishikawa S, Nishikawa S-i, Muguruma K and others. 2007. A ROCK inhibitor permits survival of dissociated human embryonic stem cells. Nat Biotech 25(6):681686.

Weuster-Botz D, Puskeiler R, Kusterer A, Kaufmann K, John GT, Arnold M. 2005. Methods and milliliter scale devices for high-throughput process design. Bioproc Biosys Eng 28:109-119.

Wu MH, Urban JP, Cui Z, Cui ZF. 2006. Development of PDMS microbioreactor with welldefined and homogenous culture environment for chondrocyte 3-D culture. Biomed Microdevices 8(4):331-40.

Youn B, S., Sen A, Kallos M, S., Behie L, A., Girgis-Gabardo A, Kurpios N, Barcelon M, Hassell J, A. 2005. Large-Scale Expansion of Mammary Epithelial Stem Cell Aggregates in Suspension Bioreactors. Biotechnology Progress 21(3):984-993.

Yu Y, Li K, Bao C, Liu T, Jin Y, Ren H, Yun W. 2009. Ex vitro expansion of human placentaderived mesenchymal stem cells in stirred bioreactor. Appl Biochem Biotechnol 159(1):110-8. 
Zhang Z, Perozziello G, Boccazzi P, Sinskey AJ, Geschke O, Jensen KF. 2007. Microbioreactors for Bioprocess Development. JALA - Journal of the Association for Laboratory Automation 12(3):143-151.

zur Nieden NI, Cormier JT, Rancourt DE, Kallos MS. 2007. Embryonic stem cells remain highly pluripotent following long term expansion as aggregates in suspension bioreactors. Journal of Biotechnology 129(3):421-432. 


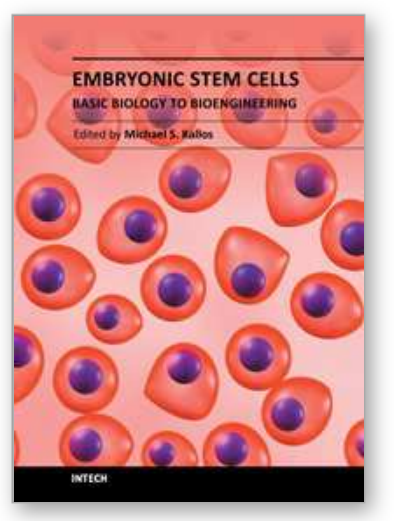

\author{
Embryonic Stem Cells - Basic Biology to Bioengineering \\ Edited by Prof. Michael Kallos
}

ISBN 978-953-307-278-4

Hard cover, 478 pages

Publisher InTech

Published online 15, September, 2011

Published in print edition September, 2011

Embryonic stem cells are one of the key building blocks of the emerging multidisciplinary field of regenerative medicine, and discoveries and new technology related to embryonic stem cells are being made at an ever increasing rate. This book provides a snapshot of some of the research occurring across a wide range of areas related to embryonic stem cells, including new methods, tools and technologies; new understandings about the molecular biology and pluripotency of these cells; as well as new uses for and sources of embryonic stem cells. The book will serve as a valuable resource for engineers, scientists, and clinicians as well as students in a wide range of disciplines.

\title{
How to reference
}

In order to correctly reference this scholarly work, feel free to copy and paste the following:

Allison Van Winkle, Ian D. Gates and Michael S. Kallos (2011). Small-Scale Bioreactors for the Culture of Embryonic Stem Cells, Embryonic Stem Cells - Basic Biology to Bioengineering, Prof. Michael Kallos (Ed.), ISBN: 978-953-307-278-4, InTech, Available from: http://www.intechopen.com/books/embryonic-stem-cellsbasic-biology-to-bioengineering/small-scale-bioreactors-for-the-culture-of-embryonic-stem-cells

\section{INTECH}

open science | open minds

\section{InTech Europe}

University Campus STeP Ri Slavka Krautzeka 83/A 51000 Rijeka, Croatia Phone: +385 (51) 770447

Fax: +385 (51) 686166 www.intechopen.com

\section{InTech China}

Unit 405, Office Block, Hotel Equatorial Shanghai No.65, Yan An Road (West), Shanghai, 200040, China 中国上海市延安西路65号上海国际贵都大饭店办公楼 405 单元 Phone: +86-21-62489820

Fax: $+86-21-62489821$ 
(C) 2011 The Author(s). Licensee IntechOpen. This chapter is distributed under the terms of the Creative Commons Attribution-NonCommercialShareAlike-3.0 License, which permits use, distribution and reproduction for non-commercial purposes, provided the original is properly cited and derivative works building on this content are distributed under the same license. 